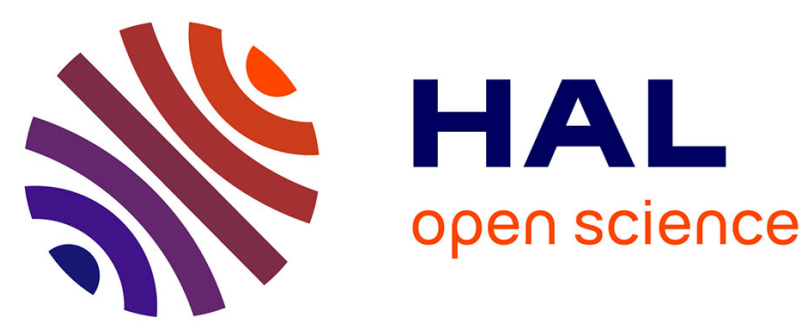

\title{
From the environment to the host: How non-azole agrochemical exposure affects the antifungal susceptibility and virulence of Cryptococcus gattii
}

Rafael Wesley Bastos, Gustavo José Cota Freitas, Hellem Cristina Silva

Carneiro, Lorena Vívien Neves Oliveira, Ludmila Gouveia-Eufrasio, Anderson

Philip Nonato Santos, Frederique Moyrand, Corinne Maufrais, Guilhem Janbon, Daniel Assis Santos

\section{- To cite this version:}

Rafael Wesley Bastos, Gustavo José Cota Freitas, Hellem Cristina Silva Carneiro, Lorena Vívien Neves Oliveira, Ludmila Gouveia-Eufrasio, et al.. From the environment to the host: How nonazole agrochemical exposure affects the antifungal susceptibility and virulence of Cryptococcus gattii. Science of the Total Environment, 2019, 681, pp.516-523. 10.1016/j.scitotenv.2019.05.094 pasteur02651897

\section{HAL Id: pasteur-02651897}

\section{https://hal-pasteur.archives-ouvertes.fr/pasteur-02651897}

Submitted on 11 Aug 2020

HAL is a multi-disciplinary open access archive for the deposit and dissemination of scientific research documents, whether they are published or not. The documents may come from teaching and research institutions in France or abroad, or from public or private research centers.
L'archive ouverte pluridisciplinaire HAL, est destinée au dépôt et à la diffusion de documents scientifiques de niveau recherche, publiés ou non, émanant des établissements d'enseignement et de recherche français ou étrangers, des laboratoires publics ou privés. 


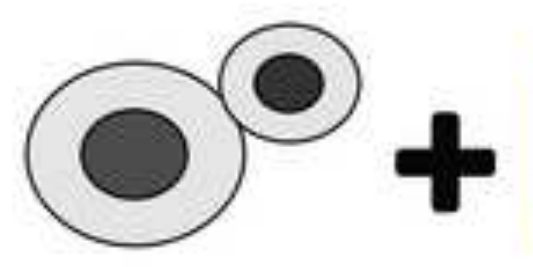

Cryptococcus spp.
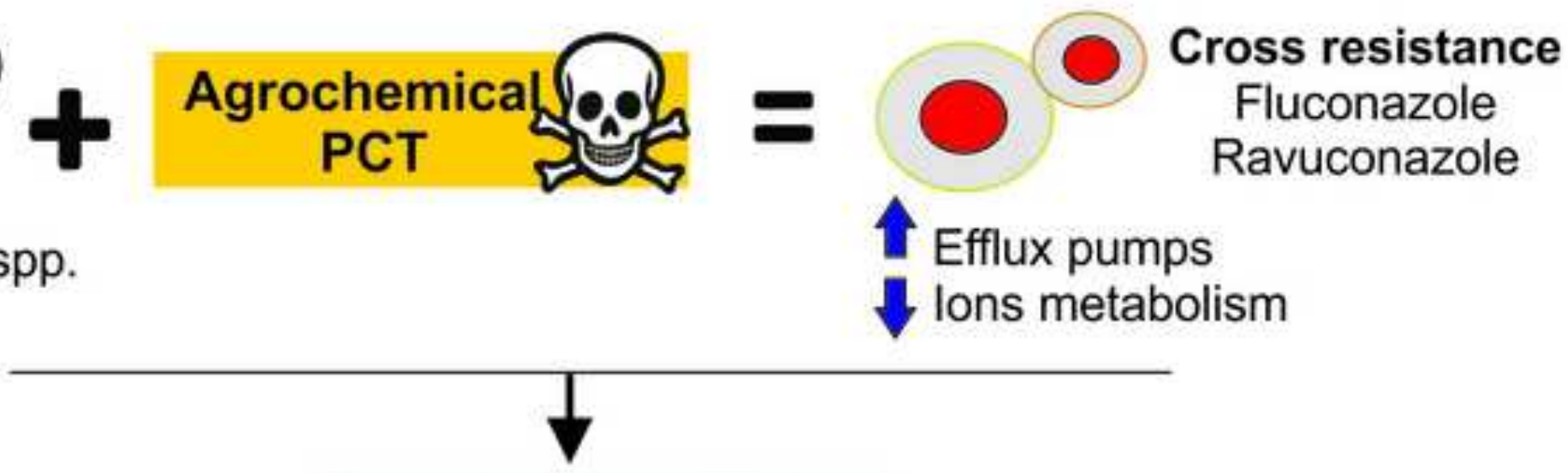

Intratracheal infection:

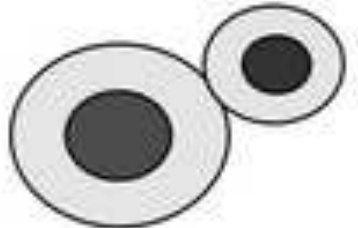

FLC susceptible in vivo Virulence
Fluconazole

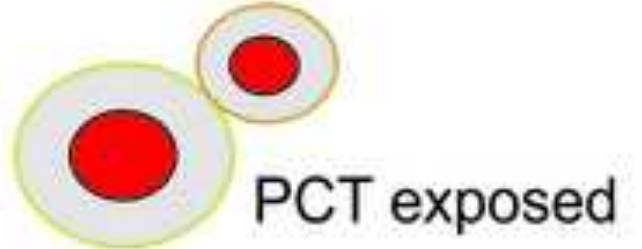

FLC resistant in vivo Virulence

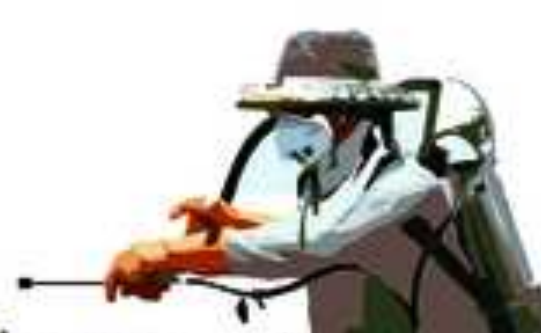




\section{Highlights}

- Exposure to pyraclostrobin induces cross-resistance with clinical antifungals in Cryptococcus

- Non-azole agrochemical exposure increases expression of efflux pumps in $C$. gattii

- Pyraclostrobin-exposed yeasts are less virulent than non-exposed ones in mice

- Fluconazole is not able to treat cryptococcosis by pyraclostrobin-exposed cells.

- Agrochemicals jeopardize animal and human health by influencing fungal resistance. 
1 From the environment to the host: how non-azole agrochemical exposure affects

2 the antifungal susceptibility and virulence of Cryptococcus gattii

3

4 Rafael Wesley Bastos ${ }^{1,2}$, Gustavo José Cota Freitas ${ }^{1}$, Hellem Cristina Silva Carneiro ${ }^{1}$,

5 Lorena Vívien Neves de Oliveira ${ }^{1}$, Ludmila Gouveia-Eufrásio ${ }^{1}$, Anderson Philip Nonato

6 Santos $^{1}$, Frédérique Moyrand ${ }^{3}$, Corinne Maufrais ${ }^{3}$, Guilhem Janbon ${ }^{3}$, Daniel Assis

$7 \quad \operatorname{Santos}^{1 *}$

8

$9{ }^{1}$ Departamento de Microbiologia, Instituto de Ciências Biológicas, Universidade Federal 10 de Minas Gerais, Belo Horizonte, Minas Gerais, Brasil.

$11{ }^{2}$ Faculdade de Ciências Farmacêuticas de Ribeirão Preto, Universidade de São Paulo, São 12 Paulo, Brasil.

$13{ }^{3}$ Département de Mycologie, Institut Pasteur, Paris, France. 


\section{Abstract}

Agrochemicals such as the non-azoles, used to improve crop productivity, poses severe undesirable effects on the environment and human health. In addition, they induce cross-resistance $(\mathrm{CR})$ with clinical drugs in pathogenic fungi. However, till date emphasis has been given to the role of azoles on the induction of CR. Herein, we analyzed the effect of a non-azole agrochemical, pyraclostrobin (PCT), on the antifungal susceptibility and virulence of the human and animal pathogens Cryptococcus gattii and C. neoformans. We determined the minimum inhibitory concentration (MIC) of fluconazole (FLC), itraconazole, ravuconazole, amphotericin B, and PCT on colonies: (i) that were not exposed to PCT (non adapted-NA-cultures), (ii) were exposed at the maximum concentration of PCT (adapted-A-cultures) and (iii) the adapted colonies after cultivation 10 times in PCT-free media (10 passages-10pcultures). Our results showed that exposure to PCT induced both temporary and permanent $\mathrm{CR}$ to clinical azoles in a temperature-dependent manner. With the objective to understand the mechanism of induction of CR through non-azoles, the transcriptomes of NA and 10p cells from C. gattii R265 were analyzed. The transcriptomic analysis showed that expression of the efflux-pump genes (AFRI and MDR1) and PCT target was higher in resistant 10p cells than that in NA. Moreover, the virulence of $10 \mathrm{p}$ cells was reduced as compared to NA cells in mice, as observed by the differential gene expression analysis of genes related to ion-metabolism. Additionally, we observed that FLC could not increase the survival rate of mice infected with 10p cells, confirming the occurrence of permanent CR in vivo. The findings of the present study demonstrate that the non-azole agrochemical PCT can induce permanent CR to clinical antifungals through increased expression of efflux pump genes in resistant cells and that such phenomenon also manifests in vivo.

Keywords: pyraclostrobin; cross-resistance; efflux pumps; fluconazole; temperature 
Introduction

The growing demand for food supply has increased the consumption of agrochemicals worldwide (Popp et al., 2013; Rigotto et al., 2014; Elahi et al., 2019). However, their intensive use leads to severe undesirable effects on the environment (Hartman et al., 2016; Cui et al., 2017) as well as human health (Rigotto et al., 2014; Elahi et al., 2019). Recently, some studies have shown that agrochemicals select microorganisms that are otherwise resistant to clinical antifungals, developing crossresistance (CR) (Ren et al., 2017; Brilhante et al., 2019; Bastos et al., 2018; Carneiro et al., 2019). In our previous work, we showed that the triazole agrochemical tebuconazole triggers permanent and temporary CR to clinical azole drugs in Cryptococcus spp., both in vitro and in vivo (Bastos et al., 2018). Nevertheless, it is uncertain whether non-azole agrochemicals such as pyraclostrobin (PCT) are also able to induce CR.

Cryptococcus gattii and Cryptococcus neoformans are the main etiologic agents of cryptococcosis, which affect more than 200,000 people per year worldwide, with a mortality rate of $81 \%$ (Rajasingham et al., 2017; Williamson et al., 2017). These microorganisms are generally found in the plant habitats. More specifically, $C$. gattii is found in more than 50 tree species, especially in Eucalyptus (Chatuverdi and Chatuverdi, 2011, Prakash et al., 2018), whereas the primary niche of C. neoformans is associated with plants as well as with birds' feces (Cogliati et al., 2016). However, it remains unclear (i) how the interaction with plants influences the biology of these fungi (Xue et al., 2007); and (ii) how human interferences, mainly, the use of agrochemicals (Del Poeta and Casadevall, 2012), affect the biology of Cryptococcus spp. the way they affect Aspergillus fumigatus (Snelders et al., 2012; Ren et al., 2017) and Candida spp. (Brilhante et al., 2019). 
The therapeutic arsenal used to treat cryptococcosis is composed of amphotericin B (AMB), 5-flucytosine, and the azoles fluconazole (FLC) and itraconazole (ITZ) (Perfect et al., 2010; Molloy et al., 2018). Despite the availability of reports showing increased resistance to azoles (Smith et al., 2015; Chen et al., 2016), the underlying mechanism of resistance is still unclear, especially in C. gattii. According to previous studies, resistance may be caused by mutations in the ERG11 gene, which encodes the drug-target protein ERG11p, and also by the overexpression of efflux pumps, e.g. AFR-1 (ATP-binding cassette transporter), AFR-2, and MDR11 (putative ABC multidrug resistance transporter similar to Ste6) (Basso et al., 2015; Yang et al., 2016, Cavalheiros et al., 2018).

The antifungal PCT is a strobilurin fungicide, which belongs to the quinone outside inhibitors (QoI) group. QoI alters mitochondrial respiration by binding to the Qo site of the cytochrome $\mathrm{b}$, blocking the electron transfer to cytochrome $\mathrm{c}_{1}$, which leads to the disruption of the energy cycle (Bartlett etal., 2002). Because of its high efficiency and broad-spectrum action against phytopathogenic fungi, it has been considered as an "environment-friendly fungicide". Hence, its consumption has increased worldwide including in the United States, United Kingdom, and China (Bartlett etal., 2002; Oliver and Hewitt, 2014; Gou et al., 2017).

Despite being considered low-toxic for humans, birds, mammals, and bees (Barlett, 2002), there are reports of poisoning caused by PCT (CDC, 2018). Furthermore, the widespread use of strobilurin fungicides, including PCT, can pose a potential risk to aquatic organisms, since residues of pesticides can remain in the air, soil, or water through runoff and/or leaching from soil to the surrounding waterbodies (Hartman, et al., 2016; Cui, et al., 2017). 

agrochemical PCT on the susceptibility of Cryptococcus spp. to clinical drugs and its virulence.

\section{Materials and Methods}

112

113

114

115

\section{Microorganisms}

We used twelve strains of $C$. gattii (eight clinical and two environmental isolates, from the culture collection of the Laboratório de Micologia, at Universidade Federal de Minas Gerais, state of Minas Gerais, Brazil; and two reference strains from the culture collection of the University of Georgia, Atlanta, GA, USA) (Table 1) (Santos et al., 2012). Besides four strains of $C$. neoformans (one clinical and three reference strains) (Magalhães et al., 2013) were also used (Table 1). All isolates were maintained in Sabouraud Dextrose Broth medium with $10 \%$ glycerol, at $-80^{\circ} \mathrm{C}$.

\section{Antifungal drug susceptibility testing}

The minimum inhibitory concentration (MIC) of FLC (Sigma-Aldrich, St. Louis, MO), AMB (Sigma-Aldrich), and the environmental antifungal PCT $\left(\mathrm{COMET}^{\circledR}\right)$ were determined by the microdilution method (MIC ${ }^{\text {broth }}$ (CLSI, 2012). The MIC of PCT was also verified by spot tests on Sabouraud Dextrose Agar (SDA) medium, supplemented with different concentrations of PCT (MIC ${ }^{\text {solid }}$ ), as previously described (Bastos et al., 2018). The $\mathrm{MIC}^{\text {broth }}$ and $\mathrm{MIC}^{\text {solid }}$ tests were performed at $30^{\circ} \mathrm{C}$ and $35^{\circ} \mathrm{C}$, and all the tests were performed in duplicates for each strain. 


\section{Agrochemical adaptationand cross-resistance tests (CR)}

Following MIC ${ }^{\text {solid }}$ tests, the strains were grown on SDA medium supplemented with increasing concentrations of the pesticide. Initially, all strains were grown on a medium supplemented with PCT at a concentration of MIC/2 (sub-MIC: half the MIC value). After the colonies have developed, an inoculum containing approximately $1 \times$ $10^{4}$ to $5 \times 10^{4}$ fungal cells was inoculated onto SDA medium supplemented with the MIC of PCT. This process was repeated, and the strains were grown in a stepwise manner, at increasing amounts of PCT (ranging from $0.25 \mathrm{mg} / \mathrm{L}$ to $256.0 \mathrm{mg} / \mathrm{L}$ ), up to the concentration at which the growth was ceased, or until the maximum limit of $256 \mathrm{mg} / \mathrm{L}$ was reached. The tests were carried out at $30^{\circ} \mathrm{C}$ and $35^{\circ} \mathrm{C}$ (Bastos et al., 2018). The highest concentration of PCT at which the fungus was capable of growing after the

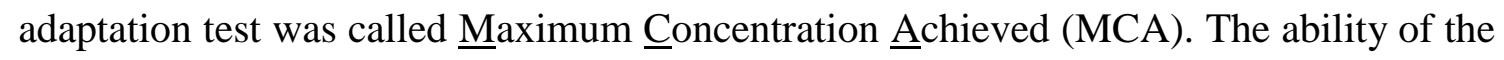
microorganisms to multiply in the presence of PCT was assessed by determining the ratio between the MCA and the sub-MIC (MCA/sub-MIC).

The colonies exposed to the agrochemicals were named PCT-adapted (A), while the original ones were called non-adapted (NA). Subsequently, the MIC broth of FLC, $\mathrm{AMB}$, and PCT were determined for the NA and A colonies. The tests were performed at two different temperatures, $30^{\circ} \mathrm{C}$ and $35^{\circ} \mathrm{C}$ ( $\mathrm{MIC}^{\text {broth }}$ incubation temperature), for the colonies adapted at $30^{\circ} \mathrm{C}$ temperature $35^{\circ} \mathrm{C}$, respectively. The strain was considered cross-resistant (CR) when it showed an increased MIC for both the agrochemical and clinical drugs. The CR was further classified either as temporary or permanent depending on the restoration of susceptibility to the drugs. In temporary CR the agrochemical-adapted colonies returned to their original susceptibility and the colonies showing permanent CR stayed susceptible to the drugs even after the withdrawal of PCT for 10 passages (10p colonies) (Bastos et al., 2018). 
PCT and ravuconazole (RVZ; Sigma-Aldrich) in PCT-adapted and 10p colonies that showed CR to FLC.

\section{Transcriptome analysis}

grown in a YPD medium without the drugs at $30^{\circ} \mathrm{C}$, for total RNA extraction (Moyrand

et al., 2008), in triplicates. For sequencing, strand-specific paired-end cDNA libraries

Kit, according to the manufacturer's instructions. cDNA fragments of $\sim 400 \mathrm{bp}$ from each library were purified and checked for their quality using a Bioanalyzer (Agilent), followed by sequencing of $100 \mathrm{bp}$ fragments from both ends using an Illumina HiSeq2000 instrument. The differential gene expression was investigated using DESeq1 v1.1659, DESeq2 v1.4.160, and edgeR v3.6.161, with default settings and false discovery rate (FDR) cutoff set at 0.05 . The genes with more than 10 mapped fragments 172 in at least one library were selected, and the fold change output from DESeq2 was 173 considered as the decisive fold change. A gene was considered significantly differentially expressed when the fold change was higher or lower than 1.5.

\section{In vivo tests}

C57BL/6 male mice, aged 6-8 weeks, were used. All experimental procedures were carried out according to the standards of the Brazilian Society of Laboratory

Animal Science/Brazilian College for Animal Experimentation 

number 306/2015).

The animals $(\mathrm{n}=6)$ were anesthetized with ketamine $(60 \mathrm{mg} / \mathrm{kg})$ and xylazine cells through the intratracheal route. Some groups were treated daily with $20 \mathrm{mg} / \mathrm{kg}$ of FLC through the intraperitoneal route (the controls are represented by the untreated groups). The mice were monitored daily for survival (Ferreira et al., 2015). Further, other groups of mice were also infected with NA and 10p cells and the animals were anesthetized and euthanized after 15 days to collect the lungs. The lungs were then homogenized in phosphate buffered saline (PBS), and plated on SDA medium. After $48 \mathrm{~h}$ of incubation at $35^{\circ} \mathrm{C}$, the recovered colonies were collected and subsequently used for the MIC ${ }^{\text {broth }}$ test.

\section{Statistical analysis} software GraphPad Prism, version 6.00 for Windows (GraphPad Software, San Diego, using the log-rank test. All analyses were repeated at least twice.

200 


\section{Adaptation process increases resistance to $\mathrm{PCT}$}

Initially, we determined the MIC of FLC, AMB, and PCT for each strain of

C.gattii and C. neoformans at $30^{\circ} \mathrm{C}$ and $35^{\circ} \mathrm{C}$. The results showed inhibition of all the

210

211

212

213

214

215

216

217

218

219

220

221

222

223

224

225

226

227

228

229

strains by the drugs when the MIC was checked in the broth medium (MIC ${ }^{\text {broth }}$ ) (data not shown) and solid medium (MIC ${ }^{\text {solid }}$ (Table 1).

MIC $^{\text {solid }}$ test revealed that all strains of $C$. gattii and C. neoformans were capable of growth at higher concentrations of PCT when the adaptation test was performed at $30^{\circ} \mathrm{C}$ (Table 1), of which, C. gattii L27/01 tolerated the agrochemical the most in the adaptation test, being able to grow in a medium 2,048 times richer in PCT (Table 1). However, the adaptation test at $35^{\circ} \mathrm{C}$ revealed that $75 \%$ of the $C$. gattii and $100 \%$ of the C. neoformans strains tolerated more the PCT (Table 1).

The geometric means of the ratio MCA/Sub-MIC at $30^{\circ} \mathrm{C}$ were observed to be higher than those at $35^{\circ} \mathrm{C}$ in both the species (Table 1), indicating the influence of the temperature on adaptation.

PCT exposure causes temporary and permanent cross-resistance with clinical azolesin a temperature-dependent manner

An increase (more than four folds) in the MIC of PCT was observed in 58.3\% $(\mathrm{n}=7)$ of the $C$. gattii strains and $100 \%(\mathrm{n}=4)$ of the C. neoformans (Tables 2 and 3) after the adaptation process at $30^{\circ} \mathrm{C}$. However, the $\mathrm{MIC}$ broth tests performed at $35^{\circ} \mathrm{C}$ identified only five strains of $C$. gattii, demonstrating less susceptibility to the pesticide. Further, all PCT-adapted colonies of $C$. neoformans adapted at $30^{\circ} \mathrm{C}$ were independent of the temperature variations (Table 3). 

of the pathogens to FLC and AMB. Tables 2 and 3 show that the geometric mean values of FLC MIC ${ }^{\text {broth }}$ for PCT-adapted cells at $30^{\circ} \mathrm{C}$ increased by more than 2.0 times for $C$. gattii. On the other hand, the geometric means of adapted cells did not differ considerably from those of NA cells (Tables 2 and 3) at $35^{\circ} \mathrm{C}$ for $C$. gattii, and at both temperatures for $C$. neoformans. It was observed that $41.6 \%(\mathrm{n}=5)$ of the $C$. gattii and $25 \%(\mathrm{n}=1)$ of the $C$. neoformans strains presented CR to FLC when the adaptation and MIC processes were performed at $30^{\circ} \mathrm{C}$ (Tables 2 to 4). Four (33.3\%) C. gattii strains (R265, ATCC 24065, L24/01, and L27/01) demonstrated permanent CR, and did not return to their original susceptibility even after growing them for 10 passages in an agrochemical-free media (Tables 2 and 4). In contrast, three strains of $C$. gattii and one strain of $C$. neoformans (ATCC 62066) exhibited a temporary CR by returning to their original susceptibility after 10 passages in a medium without PCT (Tables 2to4). The permanent and temporary CR displayed by $C$. gattii R265 and 547/OTTI/94-PI-10, respectively, were verified both at $30^{\circ} \mathrm{C}$ and $35^{\circ} \mathrm{C}$ (Table 2). The PCT-adapted cells at $30^{\circ} \mathrm{C}$ that exhibited $\mathrm{CR}$ to FLC were also found to show CR to RVZ (Table 5), but not to ITZ (Table 5) and AMB (data not shown).

Additionally, the adaptation test at $35^{\circ} \mathrm{C}$ identified higher MIC ${ }^{\text {broth }}$ of PCT for (Tables 4 and 6) and AMB (data not shown) was not observed. To investigate the permanent changes caused by the PCT exposure, we compared the RNA expression profile in NA and 10p cells of $C$. gattii R265. Both the cells were grown in a medium without PCT, at $30^{\circ} \mathrm{C}$. The analysis identified 230 genes 
showing differential expression, of which 110 were up-regulated and 120 were downregulated. Though most of these genes encode hypothetical proteins $(55.2 \%)$, the genes related to amino acid metabolism, oxidation-reduction process, sugar metabolism, transmembrane transport, nucleotide metabolism, ribosome biogenesis, drug transport, cell wall biosynthesis, and phosphatases were up-regulated in the $10 \mathrm{p}$ cells than the NA cells (Figure 1A). However, the down-regulated genes were related to the amino acid, sugar and ion metabolism, oxidation-reduction process, membrane component, transmembrane transport, and RNA metabolism (Figure 1B).

The genes like CTR4 [solute carrier family 31 (copper transporter), member 1] and FRE (ferric-chelate reductase)-1 and 7, probably involved in virulence of Cryptococcus spp. were also down-regulated (Table 7).

\section{Efflux pumps and genes encoding PCT target were up-regulated in 10p cells}

It has been proposed that Cryptococcus spp. becomes less susceptible to azole drugs due to the overexpression of ERG-11 and/or efflux-pumps genes (AFR-1, AFR-2, and MDR11) (Basso et al., 2015; Bastos et al., 2018). We searched for the genes mentioned above in the transcriptome data, to validate their role in the development of resistance to azoles. We found that $A F R 1$ and MDR11 were up-regulated (1.5 times fold change) in the 10p cells (Table 7), suggesting their role in the development of the observed phenotype. Though, we did not observe any significant difference in the expression profile of $E R G 11, C N B G \_4400$, the gene encoding cytochrome b2, the target for the agrochemical PCT, was more expressed (2.05 times fold change) in the 10p cells (Table 7). 


\section{C. gattii $\mathbf{R} 26510$ p cells are less virulent and more resistant to FLC than NA cells in}

280

281

282

283

284

285

286

287

288

289

290

291

292

293

294

295

296

297

298

299

300

301

302

303

vivo

For in vivo validation of the reduced virulence in the 10p cells, both NA and 10p cells of $C$. gattii R265 were tested in mice. All animals infected with NA cells died within 30 days of post-infection (d.p.i). On the other hand, $20 \%$ of the mice infected with 10p cells were alive 60 d.p.i. revealing their lower virulence $(\mathrm{p}<0.05)$ (Figure 2).

It was observed that the treatment with FLC increased the survival rate of NAinfected mice, as they remained alive even after 60 d.p.i. In contrast, FLC could not augment the survival of the mice infected with 10p cells (Figure 1), demonstrating the in vivo occurrence of $\mathrm{CR}$.

In addition, we tested the MIC ${ }^{\text {broth }}$ for colonies recovered from the lungs of mice infected with NA and 10p cells for 15 days. The colonies from animals infected with 10p cells were less susceptible to PCT and all the clinical azoles tested than the NA colonies (Figure1), indicating that the 10p cells of $C$. gattii R265 present in vivo CR to FLC and other azole drugs.

\section{Discussion}

The fast-growing world population calls for increasing food supply, thereby increased crop productivity. In order to achieve this, the use of agrochemicals is the most preferred alternative that helps to avoid losses due to pests such as insects and microorganism infections (Popp et al., 2013). However, these substances may pose harmful effects on human and animal health and the environment (Rigotto et al., 2014). Recently, we showed that tebuconazole, an environmental triazole, causes temporary and permanent CR to clinical azoles in C. gattii and C. neoformans (Bastos et al., 2018). However, it is not well-understood whether non-azole agrochemicals induce the same 
304

305

306

307

308

309

310

311

312

313

314

315

316

317

318

319

320

321

322

323

324

effect. In this work, we showed that the agrochemical PCT, which inhibits the activity of the cytochrome $b$ and the electron transport chain in mitochondria, is also able to select cells of Cryptococcus that are less susceptible to azole drugs (FLC, ITZ, and RVZ). PCT was chosen for this study for several reasons, including its action mechanism (non-azole), extensive use (Bartlett etal., 2002; Oliver and Hewitt, 2014; Gou et al., 2017), and broad-spectrum activity. It has also been reported to be used for Eucalyptus habitats, where Cryptococcus spp. can be found (Chatuverdi and Chatuverdi, 2011).

Temperature is a crucial factor that controls the growth of Cryptococcus. Several studies have reported its involvement in several phenomena such as the generation of titan cells, hyphal growth, inheritance patterns of mitochondria, capsule size, survival inside avian macrophages, and general virulence (Zaragoza and Casadevall, 2004; Bielska and May, 2015; Wang et al., 2015; Johnston et al. 2017; and Watkins et al., 2017; Hommel et al., 2018). In the present study, we observed that the rate of CR is dependent on the temperature at which the adaptation test was conducted. When the test was carried out at $30^{\circ} \mathrm{C}$, more strains of $C$. gattii and C. neoformans presented CR to FLC. Additionally, the lowest temperature positively influenced the concentration of PCT tolerated by the fungi. Our results show the capacity of acquiring mechanisms related to $\mathrm{CR}$ between agrochemical and azole clinical drugs, thus supporting the earlier findings. Besides, the incubation temperature during the $\mathrm{MIC}^{\text {broth }}$ tests was also relevant to the $\mathrm{CR}$ exhibited by the strains adapted at $30^{\circ} \mathrm{C}$. While some strains presented $\mathrm{CR}$ to FLC, regardless of the incubation temperature, others showed increased resistance only when the cells were incubated at $30^{\circ} \mathrm{C}$. These results reinforce that even with higher resistance in the environment at low temperatures, resistance may not manifest in animal infections due to the mammalian body temperature (Bastos et al., 2018). 
While PCT targets the mitochondrial metabolism, azole drugs act on the ergosterol synthesis. Therefore, the next question was why the cells that had been exposed to the non-azole agrochemical became less susceptible to clinical azoles. Association between mitochondrial metabolism deficiency and azole resistance in Cryptococcus has been poorly documented. Nevertheless, it has been described that $C$. neoformans becomes less susceptible to FLC when brought into contact with tetracycline, an antibiotic that interferes in the synthesis of bacterial and mitochondrial proteins (Oliver et al., 2008).

In an attempt to better understand why PCT-exposed cells become less susceptible to clinical azoles, we performed the transcriptome analysis of the NA and hypothesis for the underlying mechanism for the development of azole resistance in $10 \mathrm{p}$ cells. It could be because of pumping out of the antifungal drugs out of the cell. fungi involves mutations in the gene encoding the drug target, cytb (cytochrome b) (Yin cells, which may be the cause of the less susceptible phenotype.

Cryptococcus spp. have several virulence factors, being the following the classic ones: capsule production, ability to grow at $37^{\circ} \mathrm{C}$, and production of enzymes, among them phospholipase, urease, laccase, and SOD (Bielska and May, 2015). Recently, other important virulence pathways of this genus have been studied, which include the obtention and use of metals, like iron, copper, and zinc. These ions act as cofactors of 
several enzymes, and they are essential in processes like respiration. Because of their importance, microorganisms like Cryptococcus must be able to acquire them from the environment and from the host to ensure their growth (Silva et al., 2011). In this context, we identified that the gene CTR4 and other possible genes involved in ion metabolism were less expressed in the $10 p$ cells. CTR4p is a copper-transport protein, essential not only for copper homeostasis but also for the virulenceof $C$. neoformans, since a $\operatorname{ctr} 4 \Delta$ strain is less virulent than the corresponding wild type (Waterman et al.,2012). Thus, we hypothesize that low expression of the genes related to iron and copper obtention may lead to reduced virulence in the $10 \mathrm{p}$ cells. The less virulent phenotype was further confirmed in the mice model.

Finally, to investigate if the drug resistance observed in vitro also manifests in vivo, we infected the mice with NA and 10p cells of $C$. gattii R265 that presented CR to all clinical azoles. We then treated some of the animals with FLC, while others were kept untreated as the control. The treatment with the drug did not change the survival of the animals infected with the 10p cells, as opposed to the mice infected with NA cells. In vivo $\mathrm{CR}$ was also confirmed in colonies recovered from the lungs of animals infected with 10p cells. They were less susceptible to PCT and azoles than those obtained from animals infected with NA cells.

\section{Conclusion}

In conclusion, fungicide PCT exposure selects cells with $\mathrm{CR}$ to clinical azole drugs, both in vitro and in vivo. PCT also decreased the virulence of C. gattii R265, after contact with the agrochemical ceased. This study demonstrates the permanent implications of non-azole agrochemicals on fungal virulence and susceptibility to drugs and indicates how anthropic action in the environment could be responsible for the evolution of resistant strains of Cryptococcus spp. 
This study was supported by Fundação de Amparo a Pesquisa do Estado de

Minas Gerais - FAPEMIG (Grant APQ-00727-16 and PPM-00061-18) and Conselho

382

383

384

385

386

387

388

389

390

391

392

393

394

395

396

397

398

399

400

401

402
Nacional de Desenvolvimento Científico e Tecnológico - CNPq (Grants 403006/2016-3 and 440010/2018-7). RWB received fellowships from CNPq and Coordenação de Aperfeiçoamento de Pessoal de Nível Superior (PDSE-CAPES -88881.131683/201601). DAS is a research fellow of the CNPq (Grant 302670/2017-3).

We declare that we have no conflicts of interest.

\section{Transparency declarations.}

None to declare.

\section{Author contributions}

Conceived and designed the experiments: RWB, DAS, GJ. Performed the experiments: RWB, GJCF, HCSC, LVNO, LGE, APNS, FM. Analyzed the data: RWB, CM, DAS. Contributed reagents/materials/analysis tools: GJ, DAS. Contributed to the writing of the manuscript: RWB, GJ, DAS.

\section{Legends of the figures:}

Figure 1: Transcriptomic profile of C. gattii R265 adapted cells grown in medium without pyraclostrobin (PCT) (10p) and non-adapted (NA) cells. The function of genes (A) up- and (B) down-regulated in 10p cells compared to NA. 
Figure 2: Virulence and in vivo cross-resistance in non-adapted (NA) and adapted cells

404

405

406

407

408

409

410

411

412

413

414

415

416

417

418

419

420

421

422

423

424

425

426

427

428

429

430

431

432

433

434

435

436

grown in medium without agrochemical (10p). (A) 10p cells are significantly $(\mathrm{p}<0.05)$

less virulent than NA. The treatment with fluconazole $($ FLC) significantly $(p<0.05)$

increased the survival of mice infected with NA, but not of those infected with 10p cells. (B) Cells recovered from the lungs of animals infected with 10p colonies were more resistant to pyraclostrobin (PCT), FLC, itraconazole (ITZ) and ravuconazole (RVZ), but not to amphotericin B (AMB) than those recovered from NA-infected mice. $* \mathrm{p}<0.05 ; * * \mathrm{p}<0.01$

\section{References}

BIELSKA, E; MAY, R. C. What makes Cryptococcus gattii a pathogen? FEMS Yeast Res, v. 16, n. 1, p. fov106, 2016.

BARTletT, D. W. et al. The strobilurin fungicides. Pest Manag Sci, v. 58, n. 7, p. 649-62, 2002.

BASSO, L. R. et al. Identification and properties of plasma membrane azole efflux pumps from the pathogenic fungi Cryptococcus gattii and Cryptococcus neoformans. $\mathbf{J}$ Antimicrob Chemother, v. 70, n. 5, p. 1396-407, 2015.

BASTOS R. W. et al.. 2018. Environmental triazole induces crossresistance to clinical drugs and affects morphophysiology and virulence of Cryptococcus gattii and $C$. neoformans. Antimicrob Agents Chemother 62:e1179-17, 2018.

BRILHANTE, R. S. N. et al. Exposure of Candida parapsilosis complex to agricultural azoles: an overview of the role of environmental determinants for the development of resistance. Sci Total Environ, v.650(Pt 1), p. 1231-1238, 2019.

CAVALHEIROS et al., 2018. Host-pathogen interactions mediated by mdr transporters in fungi: as pleiotropic as it gets! Genes (Basel). V. 9, n. 7, pii: E332.

CDC (Centers for Disease Control and Prevention). Acute pesticide poisoning associated with pyraclostrobin fungicide-Iowa, 2007. MMWR Morb Mortal Wkly Rep v. $56(51-52): 1343-5,2008$.

CHATURVEDI, V.; CHATURVEDI, S. Cryptococcus gattii: a resurgent fungal pathogen. Trends Microbiol, v. 19, n. 11, p. 564-71, 2011.

CHEN, Y. C, et al. Increasing trend of fluconazole-non-susceptible Cryptococcus neoformans in patients with invasive cryptococcosis: a 12-year longitudinal study. BMC Infect Dis, v.15, n.277, p. 1-7. 2015. 
CLINICAL AND LABORATORY STANDARDS INSTITUTE. Reference method for broth dilution antifungal susceptibility testing of yeasts: fourth informational supplement, CLSI document M27- S4. Clinical and Laboratory Standards Institute, Wayne, PA, 2012.

COGLIATI, M. et al. Environmental distribution of Cryptococcus neoformans and $C$. gattii around the Mediterranean basin. FEMS Yeast Res, v. 16: pii: fow045, 2016.

CUI, F, et al. Toxicity of three strobilurins (kresoxim-methyl, pyraclostrobin, and trifloxystrobin) on Daphnia magna. Environmental Toxicology and Chemistry, vol. 36, n. 1, p. 182-9, 2017.

DEL POETA, M.; CASADEVALL A. Ten challenges on Cryptococcus and cryptococcosis. Mycopathologia, v. 173, p. 303-10, 2012.

ELAHI, E, et al. Agricultural intensification and damages to human health in relation to agrochemicals: Application of artificial intelligence. Land Use Policy, v. 83, p. 461474, 2019.

FERREIRA, G. F, et al. Heteroresistance to Itraconazole Alters the Morphology and Increases the Virulence of Cryptococcus gattii. Antimicrob Agents Chemother, v. 59, n. 8, p. 4600-9, 2015.

GUO, X. et al. Residue dynamics and risk assessment of pyraclostrobin in rice, plants, hulls, field soil, and paddy water. Human and Ecological Risk Assessment: An International Journal, v. 23, n.1, p. 67-81, 2017.

HARTMAN, E. A. et al . Chronic effects of strobilurin fungicides on development, growth, and mortality of larval Great Plains toads (Bufo cognatus). Ecotoxicology v. 23, p. 396-403, 2014.

HOMMEL, B. et al. Titan cells formation in Cryptococcus neoformans is finely tuned by environmental conditions and modulated by positive and negative genetic regulators. PLoS Pathog, v. 14, n.5: e1006982, 2018.

JOHNSTON, S. A.; VOELZ, K.; MAY, R. C. Cryptococcus neoformans thermotolerance to avian body temperature is sufficient for extracellular growth but not intracellular survival in macrophages. Sci Rep, v. 6, 20977, 2016.

MAGALHÃES, T. F. et al Hydroxyaldimines as potent in vitro anticryptococcal agents.

MOLLOY, S. F. et al. Antifungal combinations for treatment of cryptococcal meningitis in africa. N Engl J Med, v. 378, n. 11, p. 1004-1017, 2018.

MOYRAND, F. et al. UGE1 and UGE2 regulate the UDP-glucose/UDP-galactose equilibrium in Cryptococcus neoformans. Eukaryot Cell, v. 7, p. 2069-77, 2008.

OLIVER. B. G., et al. Tetracycline alters drug susceptibility in Candida albicans and other pathogenic fungi. Microbiology, v. 154, p. 960-970, 2008.

OLIVER, R. P. , HEWITT HG. Fungicides in crop protection. 2. CABI, 2014.

PERFECT, J. R. et al. Clinical practice guidelines for the management of cryptococcal disease: 2010 update by the infectious diseases society of america. Clin Infect Dis, v. 50, n. 3, p. 291-322, 2010. 
PRAKASH A. et al. Environmental distribution of Cryptococcus species and some other yeast-like fungi in India. Mycoses. V. 61, n. 5, p. 305- 13, 2018. POPP, J. et al. Pesticide productivity and food security: a review. Agron Sustain Dev, v. 34, n. 1, p. 243-55, 2013. PRAKASH A., et al. Environmental distribution of Cryptococcus species and some other yeast-like fungi in India. Mycoses. V. 61, n. 5. p: 305-13, 2018.

RAJASINGHAM, R. et al. Global Burden of Disease of HIV-Associated Cryptococcal Meningitis: An Updated Analysis. Lancet Infect. Dis, v. 3099, p. 1-9, 2017.

REN, J. et al. Fungicides induced triazole-resistance in Aspergillus fumigatus associated with mutations of TR46/Y121F/T289A and its appearance in agricultural fields.J Hazard Mater. v. 326, p. 54-60, 2017.

RIGOTTO, R. M.; VASCONCELOS, D. P.; ROCHA, M. M. Pesticide use in Brazil and problems for public health. Cad Saude Publica, v. 30, n. 7, p. 1360-2, 2014.

SANTOS, J. R. et al. Dynamic interaction between fluconazole and amphotericin B against Cryptococcus gattii. Antimicrob Agents Chemother, v. 56, n. 5, p. 2553-8, 2012

SILVA, M. G. et al. The homeostasis of iron, copper, and zinc in Paracoccidioides brasiliensis, Cryptococcus neoformans var. grubii, and Cryptococcus gattii: a comparative analysis. Front Microbiol, 2:49, 2011.

SMITH, K. D. et al. Increased Antifungal Drug Resistance in Clinical Isolates of Cryptococcus neoformans in Uganda. Antimicrob Agents Chemother, v. 59, n. 12, p. 7197-204, 2015.

SNELDERS, E. et al. Triazole fungicides can induce cross-resistance to medical triazoles in Aspergillus fumigatus. PLoS One, v. 7, n. 3, p. e31801, 2012.

XUE, C. et al. The human fungal pathogen Cryptococcus can complete its sexual cycle during a pathogenic association with plants. Cell Host Microbe, v. 1, n. 4, p. 263-73, 2007.

WANG, Z.; WILSON, A.; XU, J. Mitochondrial DNA inheritance in the human fungal pathogen Cryptococcus gattii. Fungal Genet Biol, v. 75, p. 1-10, 2015.

WATERMAN, S. R. et al. Role of CTR4 in the virulence of Cryptococcus neoformans. mBio, v. 3, n. 5, e00285-12, 2012.

WATKINS, R. A; KING, J. S.; JOHNSTON, S. A. Nutritional requirements and their importance for virulence of pathogenic Cryptococcus species. Microorganisms. v. 5, n.4, p. 1-20, 2017.

512 WILLIAMSON, P. R. et al. Cryptococcal meningitis: epidemiology, immunology, 513 diagnosis and therapy. Nat Rev Neurol, v. 13, n. 1, p. 13-24, 2017.

514 YANG, M. L. et al. Fluconazole Susceptibility in Cryptococcus gattii Is Dependent on 515 the ABC Transporter Pdr11. Antimicrob Agents Chemother, v. 60, n. 3, p. 1202-7, 5162016.

517 YIN, Y. N. et al. Molecular characterization of pyraclostrobin resistance and structural 518 diversity of the cytochrome b gene in Botrytis cinerea from apple. Phytopathology, v. 
520 ZARAGOZA, O.; CASADEVALL A. Experimental modulation of capsule size in 521 Cryptococcus neoformans. Biol Proced Onli 
Table 1.Screening of subpopulations of $C$. gattii and C. neoformans strains less susceptible to pyraclostrobin (PCT-adaptation).

\begin{tabular}{|c|c|c|c|c|c|c|}
\hline \multirow{2}{*}{$\begin{array}{c}\text { Strain or parameter } \\
\text { C.gattii }\end{array}$} & \multicolumn{2}{|c|}{$\mathrm{MIC}^{\text {solid }}(\mathrm{mg} / \mathrm{L})$} & \multicolumn{2}{|c|}{ MCA (mg/L) } & \multicolumn{2}{|c|}{ MCA/Sub-MIC ${ }^{\text {solid }}$} \\
\hline & $30^{\circ} \mathrm{C}$ & $35^{\circ} \mathrm{C}$ & $30^{\circ} \mathrm{C}$ & $35^{\circ} \mathrm{C}$ & $30^{\circ} \mathrm{C}$ & $35^{\circ} \mathrm{C}$ \\
\hline R265 (C) & 1.0 & 1.0 & 200.0 & 1.0 & 400.0 & 2.0 \\
\hline ATCC 24065 (R) & 1.0 & 0.5 & 256.0 & 1.0 & 512.0 & 4.0 \\
\hline ATCC 32608 (R) & 1.0 & 0.5 & 10.0 & 1.0 & 20.0 & 4.0 \\
\hline $\begin{array}{c}\text { 547/OTTI/94- } \\
\text { PI-10 (E) }\end{array}$ & 1.0 & 0.5 & 1.0 & 1.0 & 2.0 & 4.0 \\
\hline ICB $181(\mathrm{E})$ & 1.0 & 1.0 & 10.0 & 0.5 & 20.0 & 2.0 \\
\hline $\mathrm{L} 24 / 01(\mathrm{C})$ & 1.0 & 1.0 & 1.0 & 0.5 & 2.0 & 2.0 \\
\hline $\mathrm{L} 27 / 01(\mathrm{C})$ & 0.25 & 0.25 & 256.0 & 0.5 & $2,048.0$ & 4.0 \\
\hline $\mathrm{L} 28 / 02(\mathrm{C})$ & 0.25 & 1.0 & 0.5 & 0.5 & 4.0 & 1.0 \\
\hline 1913/ER (C) & 1.0 & 2.0 & 256.0 & 256.0 & 512.0 & 256.0 \\
\hline LMM 818 (C) & 2.0 & 2.0 & 256.0 & 1.0 & 256.0 & 1.0 \\
\hline 23/10893 (C) & 1.0 & 2.0 & 12.0 & 1.0 & 24.0 & 1.0 \\
\hline 29/10893 (C) & 1.0 & 2.0 & 256.0 & 175.0 & 512.0 & 175.0 \\
\hline Range & $0.25-2.0$ & $0.25-2.0$ & $1.0-256.0$ & $1.0-256.0$ & $2.0-2,048.0$ & $1.0-256.0$ \\
\hline Geometric mean & 0.84 & 0.94 & 26.71 & 1.93 & 63.63 & 4.60 \\
\hline C. neoformans & $30^{\circ} \mathrm{C}$ & $35^{\circ} \mathrm{C}$ & $30^{\circ} \mathrm{C}$ & $35^{\circ} \mathrm{C}$ & $30^{\circ} \mathrm{C}$ & $35^{\circ} \mathrm{C}$ \\
\hline H99 (C) & 1.0 & 1.0 & 2.0 & 2.0 & 4.0 & 4.0 \\
\hline ATCC 24067 (R) & 0.5 & 2.0 & 2.0 & 2.0 & 8.0 & 2.0 \\
\hline ATCC 28957 (R) & 1.0 & 2.0 & 10.0 & 2.0 & 20.0 & 2.0 \\
\hline ATCC 62066 (R) & 1.0 & 2.0 & 2.0 & 2.0 & 4.0 & 2.0 \\
\hline Range & $0.5-1.0$ & $1.0-2.0$ & $2.0-10.0$ & 2.0 & $4.0-20.0$ & $2.0-4.0$ \\
\hline Geometric mean & 0.84 & 1.68 & 2.99 & 2.0 & 7.11 & 2.38 \\
\hline
\end{tabular}

MIC $^{\text {solid }}$ : Minimum Inhibitory Concentration of pyraclostrobin on a solid medium, before the adaptation process.MCA: Maximum Concentration Achieved by pyraclostrobin in the PCTadaptation test. C: clinical strain; R: reference strain; E: environmental strain. 
Table 2. Minimum inhibitory concentrations (MICs.mg/L) of fluconazole and pyraclostrobin for non-adapted (NA) cells of $C$. gattii strains .PCT-adapted (A) at $30^{\circ} \mathrm{C}$ and PCT-adapted colonies subcultured 10 times in agrochemical-free medium $\left(10 \mathrm{p}-10\right.$ passages). Tests were performed at $30^{\circ} \mathrm{C}$ and $35^{\circ} \mathrm{C}$.

\begin{tabular}{|c|c|c|c|c|c|c|c|c|c|c|c|c|}
\hline \multirow{3}{*}{ Strain or parameter } & \multicolumn{6}{|c|}{ Fluconazole $^{a}$} & \multicolumn{6}{|c|}{ Pyraclostrobin $^{b}$} \\
\hline & \multicolumn{3}{|c|}{ Temperature $30^{\circ} \mathrm{C}$} & \multicolumn{3}{|c|}{ Temperature $35^{\circ} \mathrm{C}$} & \multicolumn{3}{|c|}{ Temperature $30^{\circ} \mathrm{C}$} & \multicolumn{3}{|c|}{ Temperature $35^{\circ} \mathrm{C}$} \\
\hline & NA & $\mathbf{A}$ & $10 p$ & NA & $\mathbf{A}$ & $10 p$ & NA & $\mathbf{A}$ & $10 p$ & NA & $\mathbf{A}$ & $10 p$ \\
\hline R265 & 8.0 & $\begin{array}{l}128.0 \\
(16 X)\end{array}$ & $\begin{array}{l}128.0 \\
(16 X)\end{array}$ & 8.0 & $\begin{array}{l}32.0 \\
(4 X)\end{array}$ & $\begin{array}{l}32.0 \\
(4 X)\end{array}$ & 1.0 & $\begin{array}{c}16.0 \\
(16 X)\end{array}$ & $\begin{array}{c}8.0 \\
(16 X)\end{array}$ & 0.5 & $\begin{array}{c}2.0 \\
(4 X)\end{array}$ & $\begin{array}{c}2.0 \\
(4 X)\end{array}$ \\
\hline ATCC 24065 & 4.0 & $\begin{array}{l}16.0 \\
(4 X)\end{array}$ & $\begin{array}{l}16.0 \\
(4 X)\end{array}$ & 4.0 & 4.0 & ND & 0.125 & $\begin{array}{c}1.0 \\
(\mathbf{8 X})\end{array}$ & $\begin{array}{c}1.0 \\
(\mathbf{8 X})\end{array}$ & 0.125 & $\begin{array}{c}1.0 \\
(8 X)\end{array}$ & $\begin{array}{c}1.0 \\
(\mathbf{8 X})\end{array}$ \\
\hline ATCC 32608 & 16.0 & 32.0 & ND & 8.0 & 16.0 & ND & 2.0 & 4.0 & ND & 1.0 & 2.0 & ND \\
\hline 547/OTTI/94-PI-10 & 16.0 & $\begin{array}{c}128.0 \\
(8 X)\end{array}$ & 16.0 & 8.0 & $\begin{array}{l}32.0 \\
(4 X)\end{array}$ & 8.0 & 1.0 & $\begin{array}{c}8.0 \\
(\mathbf{8 X})\end{array}$ & 1.0 & 1.0 & $\begin{array}{c}4.0 \\
(4 X)\end{array}$ & 1.0 \\
\hline ICB 181 & 16.0 & 16.0 & ND & 8.0 & 16.0 & ND & 0.5 & $\begin{array}{c}4.0 \\
(8 X)\end{array}$ & $\begin{array}{c}4.0 \\
(8 X)\end{array}$ & 0.25 & $\begin{array}{c}1.0 \\
(4 X)\end{array}$ & $\begin{array}{c}2.0 \\
(\mathbf{8 X})\end{array}$ \\
\hline $\mathrm{L} 24 / 01$ & 16.0 & $\begin{array}{l}64.0 \\
(4 X)\end{array}$ & $\begin{array}{l}64.0 \\
(4 X)\end{array}$ & 8.0 & 16.0 & ND & 0.25 & $\begin{array}{c}1.0 \\
(4 X)\end{array}$ & $\begin{array}{c}2.0 \\
(\mathbf{8 X})\end{array}$ & 0.25 & $\begin{array}{c}1.0 \\
(4 X)\end{array}$ & $\begin{array}{c}2.0 \\
(\mathbf{8 X})\end{array}$ \\
\hline $\mathrm{L} 27 / 01$ & 16.0 & $\begin{array}{l}64.0 \\
(4 X)\end{array}$ & $\begin{array}{l}64.0 \\
(4 X)\end{array}$ & 32.0 & 16.0 & ND & 1.0 & $\begin{array}{c}128.0 \\
(128 X)\end{array}$ & $\begin{array}{c}4.0 \\
(4 X)\end{array}$ & 2.0 & 1.0 & ND \\
\hline $\mathrm{L} 28 / 02$ & 32.0 & 64.0 & ND & 16.0 & 32.0 & ND & 1.0 & 1.0 & ND & 0.5 & 1.0 & ND \\
\hline 1913/ER & 16.0 & 32.0 & ND & 16.0 & 8.0 & ND & 8.0 & 8.0 & ND & 1.0 & 2.0 & $\mathrm{ND}$ \\
\hline LMM 818 & 16.0 & 16.0 & ND & 16.0 & 8.0 & ND & 8.0 & 8.0 & ND & 2.0 & 4.0 & $\mathrm{ND}$ \\
\hline $23 / 10893$ & 8.0 & 4.0 & ND & 8.0 & 4.0 & ND & 4.0 & 4.0 & ND & 4.0 & 4.0 & $\mathrm{ND}$ \\
\hline $29 / 10933$ & 8.0 & 16.0 & ND & 4.0 & 4.0 & ND & 4.0 & $\begin{array}{l}128.0 \\
(32 X)\end{array}$ & $\begin{array}{l}128.0 \\
(32 X)\end{array}$ & 4.0 & 4.0 & ND \\
\hline MIC range & $4.0-32.0$ & $4.0-128.0$ & ND & $4.0-32.0$ & $4.0-32.0$ & ND & $0.125-8.0$ & $1.0-128.0$ & ND & $0.125-4.0$ & $1.0-4.0$ & ND \\
\hline Geometric mean & 12.70 & 28.50 & ND & 9.51 & 11.98 & ND & 1.33 & 6.72 & ND & 0.84 & 1.88 & ND \\
\hline
\end{tabular}

$a$ : MIC endpoint considering 50\% of growth inhibition; $b$ : MIC endpoint considering $100 \%$ of growth inhibition. The number in parentheses shows how many times (X) the MIC value of the PCT-adapted or 10p colonies was higher $(\geq 4 \mathrm{X})$ than the MIC of the NA colonies. Values in bold indicate an increase in the MIC by at least $4 \mathrm{X}$ more than in theNA colonies. ND $=$ not determined. 
Table 3. Minimum inhibitory concentrations (MICs.mg/L) of fluconazole and pyraclostrobin for non-adapted (NA) cells, PCT-adapted (A) at $30^{\circ} \mathrm{C}$ and PCTadapted colonies subcultured 10 times in agrochemical-free medium (10p - 10 passages) of $C$. neoformans strains. Tests were performed at $30^{\circ} \mathrm{C}$ and $35^{\circ} \mathrm{C}$.

\begin{tabular}{|c|c|c|c|c|c|c|c|c|c|c|c|c|}
\hline \multirow{3}{*}{ Strain or parameter } & \multicolumn{6}{|c|}{ Fluconazole $^{a}$} & \multicolumn{6}{|c|}{ Pyraclostrobin $^{b}$} \\
\hline & \multicolumn{3}{|c|}{ Temperature $30{ }^{\circ} \mathrm{C}$} & \multicolumn{3}{|c|}{ Temperature $35^{\circ} \mathrm{C}$} & \multicolumn{3}{|c|}{ Temperature $30{ }^{\circ} \mathrm{C}$} & \multicolumn{3}{|c|}{ Temperature $35^{\circ} \mathrm{C}$} \\
\hline & NA & A & $10 p$ & NA & A & $10 p$ & NA & A & $10 p$ & NA & A & $10 p$ \\
\hline H99 & 16.0 & 16.0 & ND & 8.0 & 8.0 & ND & 0.5 & $\begin{array}{c}128.0 \\
(256 X)\end{array}$ & $\begin{array}{c}8.0 \\
(16 X)\end{array}$ & 0.5 & $\begin{array}{c}2.0 \\
(4 X)\end{array}$ & $\begin{array}{c}2.0 \\
(\mathbf{4 X})\end{array}$ \\
\hline ATCC 24067 & 16.0 & 8.0 & ND & 4.0 & 2.0 & ND & 2.0 & $\begin{array}{l}128.0 \\
(64 X)\end{array}$ & $\begin{array}{l}128.0 \\
(64 X)\end{array}$ & 1.0 & $\begin{array}{c}128.0 \\
(128 X)\end{array}$ & $\begin{array}{c}32.0 \\
(32 X)\end{array}$ \\
\hline ATCC 28957 & 4.0 & 8.0 & ND & 2.0 & 2.0 & ND & 0.5 & $\begin{array}{c}8.0 \\
(16 X)\end{array}$ & $\begin{array}{c}4.0 \\
(\mathbf{8 X})\end{array}$ & 0.25 & $\begin{array}{c}1.0 \\
(4 X)\end{array}$ & $\begin{array}{l}2.0 \\
(8 X)\end{array}$ \\
\hline ATCC 62066 & 4.0 & $\begin{array}{l}16.0 \\
(4 X)\end{array}$ & 8.0 & 4.0 & 4.0 & ND & 1.0 & $\begin{array}{c}8.0 \\
(4 X) \\
\end{array}$ & 2.0 & 1.0 & $\begin{array}{c}4.0 \\
(4 X) \\
\end{array}$ & 2.0 \\
\hline MIC range & $4.0-16.0$ & $8.0-16.0$ & ND & $2.0-8.0$ & $2.0-8.0$ & ND & $0.25-1.0$ & $8.0-128.0$ & ND & $0.25-1.0$ & $1.0-128.0$ & ND \\
\hline Geometric mean & 8.0 & 11.31 & $\mathrm{ND}$ & 4.0 & 3.36 & $\mathrm{ND}$ & 0.84 & 32.0 & ND & 0.59 & 5.65 & ND \\
\hline
\end{tabular}

$a$ : MIC endpoint considering 50\% of growth inhibition; $b$ : MIC endpoint considering $100 \%$ of growth inhibition. The number in parentheses shows how many times (X) the MIC value of the PCT-adapted or 10p colonies was higher $(\geq 4 \mathrm{X})$ than the MIC of the NA colonies. Values in bold indicate an increase in the MIC by at least $4 \mathrm{X}$ more than in the NA colonies. ND = not determined. 
Table 4. Percentage (\%) of cross-resistance (CR) between PCT and FLC presented by C. gattii and C. neoformans strains after PCT-adaptation at $30^{\circ} \mathrm{C}$ and $35^{\circ} \mathrm{C}$.

\begin{tabular}{ccc|cc}
\hline \multirow{2}{*}{ Resistance } & \multicolumn{2}{c|}{ C. gattii } & \multicolumn{2}{c}{ C. neoformans } \\
\cline { 2 - 5 } & $30^{\circ} \mathrm{C}$ & $35^{\circ} \mathrm{C}$ & $30^{\circ} \mathrm{C}$ & $35^{\circ} \mathrm{C}$ \\
\hline $\begin{array}{c}\text { Cross- resistance } \\
(\mathrm{CR})\end{array}$ & 41.6 & 0 & 25 & 0 \\
Temporary CR & 8.3 & 0 & 25 & 0 \\
Permanent CR & 33.3 & 0 & 0 & 0 \\
\hline
\end{tabular}


Table 5. Minimum inhibitory concentrations (MICs.mg/L) of itraconazole and ravuconazole for non-adapted (NA) cells of C. gattii and C. neorofomans strains. PCT-adapted (A) at $30^{\circ} \mathrm{C}$ and PCT-adapted colonies subcultured 10 times in agrochemical-free medium (10p-10 passages). Tests were performed at $30^{\circ} \mathrm{C}$ and $35^{\circ} \mathrm{C}$.

\begin{tabular}{|c|c|c|c|c|c|c|c|c|c|c|c|c|}
\hline \multirow{3}{*}{$\begin{array}{l}\text { Strain } \\
\text { C. gattii }\end{array}$} & \multicolumn{6}{|c|}{ Itraconazole $^{a}$} & \multicolumn{6}{|c|}{ Ravuconazole $^{a}$} \\
\hline & \multicolumn{3}{|c|}{ Temperature $30^{\circ} \mathrm{C}$} & \multicolumn{3}{|c|}{ Temperature $35^{\circ} \mathrm{C}$} & \multicolumn{3}{|c|}{ Temperature $30^{\circ} \mathrm{C}$} & \multicolumn{3}{|c|}{ Temperature $35^{\circ} \mathrm{C}$} \\
\hline & NA & $\mathbf{A}$ & $10 p$ & NA & $\mathbf{A}$ & $10 p$ & NA & $\mathbf{A}$ & $10 p$ & NA & A & $10 p$ \\
\hline R265 & 0.5 & 1.0 & 1.0 & 0.25 & 0.25 & 0.5 & 0.125 & $\begin{array}{c}2.0 \\
(16 X)\end{array}$ & $\begin{array}{c}2.0 \\
(16 X)\end{array}$ & 0.03 & $\begin{array}{l}0.12 \\
(4 X)\end{array}$ & $\begin{array}{l}0.12 \\
(4 X)\end{array}$ \\
\hline ATCC 24065 & 0.5 & 1.0 & 0.5 & 0.25 & 0.5 & 0.5 & 0.06 & $\begin{array}{l}0.25 \\
(4 X)\end{array}$ & 0.125 & 0.03 & $\begin{array}{l}0.12 \\
(4 X)\end{array}$ & 0.03 \\
\hline 547/OTTI/94-PI-10 & 0.5 & 1.0 & ND & 0.25 & 0.5 & ND & 0.25 & $\begin{array}{c}1.0 \\
(\mathbf{4 X})\end{array}$ & ND & 0.06 & $\begin{array}{l}0.25 \\
(4 X)\end{array}$ & ND \\
\hline $\mathrm{L} 24 / 01$ & 1.0 & 1.0 & 1.0 & 0.5 & 1.0 & 1.0 & 0.125 & $\begin{array}{c}1.0 \\
(\mathbf{8 X})\end{array}$ & $\begin{array}{c}\mathbf{1 . 0} \\
(\mathbf{8 X})\end{array}$ & 0.06 & $\begin{array}{c}0.5 \\
(\mathbf{8 X})\end{array}$ & $\begin{array}{l}0.25 \\
(4 X)\end{array}$ \\
\hline $\mathrm{L} 27 / 01$ & 0.25 & 0.25 & 0.5 & 0.25 & 0.25 & 0.25 & 0.125 & $\begin{array}{c}0.5 \\
(4 \mathrm{X})\end{array}$ & $\begin{array}{c}0.5 \\
(\mathbf{4 X})\end{array}$ & 0.03 & $\begin{array}{l}0.25 \\
(4 X)\end{array}$ & $\begin{array}{l}0.25 \\
(4 X)\end{array}$ \\
\hline C. neoformans & NA & A & $10 p$ & NA & A & $10 p$ & NA & A & $10 p$ & NA & A & $10 p$ \\
\hline ATCC 62066 & 0.25 & 0.5 & ND & 0.25 & 0.5 & ND & 0.03 & $\begin{array}{c}0.5 \\
(\mathbf{1 6 X})\end{array}$ & ND & 0.031 & $\begin{array}{l}0.12 \\
(\mathbf{4 X})\end{array}$ & ND \\
\hline
\end{tabular}

$a$ : MIC endpoint considering $50 \%$ of growth inhibition. The number in parentheses shows how many times (X) the MIC value of the PCT-adapted or 10p colonies was higher $(\geq 4 \mathrm{X})$ than the MIC of the NA colonies. Values in bold indicate an increase in the MIC by at least $4 \mathrm{X}$ more than in the NA colonies. ND $=$ not determined. 
Table 6. Minimum inhibitory concentrations (MICs.mg/L) of fluconazole and pyraclostrobin for non-adapted (NA) cells of C. gattii and C. neoformans strains.PCT-adapted (A) at $35^{\circ} \mathrm{C}$ and PCT-adapted colonies subcultured 10 times in agrochemical-free medium (10p - 10 passages). Tests were performed at $35^{\circ} \mathrm{C}$.

\begin{tabular}{|c|c|c|c|c|c|c|}
\hline \multirow{2}{*}{$\frac{\text { Strain or parameter }}{C \text {. gattii }}$} & \multicolumn{3}{|c|}{ Fluconazole $^{a}$} & \multicolumn{3}{|c|}{ Pyraclostrobin $^{b}$} \\
\hline & NA & $\mathbf{A}$ & 10p & NA & $\mathbf{A}$ & $10 p$ \\
\hline R265 & 8.0 & 8.0 & ND & 0.5 & 1.0 & ND \\
\hline ATCC 24065 & 4.0 & 4.0 & ND & 0.125 & 0.25 & ND \\
\hline ATCC 32608 & 8.0 & 8.0 & ND & 1.0 & 1.0 & $\mathrm{ND}$ \\
\hline 547/OTTI/94-PI-10 & 8.0 & 16.0 & ND & 1.0 & 2.0 & ND \\
\hline ICB 181 & 8.0 & 8.0 & ND & 0.25 & $\begin{array}{c}1.0 \\
(4 X)\end{array}$ & 0.5 \\
\hline $\mathrm{L} 24 / 01$ & 8.0 & 16.0 & ND & 0.25 & 0.25 & ND \\
\hline L27/01 & 32.0 & 16.0 & ND & 2.0 & $\begin{array}{c}8.0 \\
(4 X)\end{array}$ & $\begin{array}{c}8.0 \\
(4 X)\end{array}$ \\
\hline $\mathrm{L} 28 / 02$ & 16.0 & 16.0 & ND & 0.5 & 1.0 & ND \\
\hline 1913/ER & 16.0 & 16.0 & ND & 1.0 & 2.0 & ND \\
\hline LMM 818 & 16.0 & 8.0 & ND & 2.0 & 4.0 & ND \\
\hline $23 / 10893$ & 8.0 & 4.0 & ND & 4.0 & 8.0 & ND \\
\hline $29 / 10933$ & 4.0 & 4.0 & ND & 4.0 & 2.0 & ND \\
\hline MIC range & $4.0-32.0$ & $4.0-16.0$ & ND & $0.125-4.0$ & $0.25-8.0$ & ND \\
\hline Geometric mean & 9.51 & 8.97 & ND & 0.84 & 1.49 & $\mathrm{ND}$ \\
\hline C. neoformans & NA & $\mathbf{A}$ & $10 p$ & NA & $\mathbf{A}$ & $10 p$ \\
\hline H99 & 8.0 & 16.0 & ND & 0.5 & 0.5 & ND \\
\hline ATCC 24067 & 4.0 & 8.0 & ND & 1.0 & $\begin{array}{l}16.0 \\
(16 \mathrm{X})\end{array}$ & $\begin{array}{c}4.0 \\
(4 X)\end{array}$ \\
\hline ATCC 28957 & 2.0 & 4.0 & ND & 0.25 & 0.5 & ND \\
\hline ATCC 62066 & 4.0 & 4.0 & ND & 1.0 & 1.0 & ND \\
\hline MIC range & $2.0-8.0$ & $4.0-16.0$ & ND & $0.25-1.0$ & $0.5-16.0$ & $\mathrm{ND}$ \\
\hline Geometric mean & 4.0 & 6.72 & ND & 0.59 & 1.41 & ND \\
\hline
\end{tabular}

$a$ : MIC endpoint considering 50\% of growth inhibition; $b$ : MIC endpoint considering $100 \%$ of growth inhibition. The number in parentheses shows how many times (X) the MIC value of the PCT-adapted or $10 \mathrm{p}$ colonies was higher $(\geq 4 \mathrm{X})$ than the MIC of the NA colonies. Values highlighted indicate an increase in the MIC by at least $4 \mathrm{X}$ more than in theNA colonies. ND = not determined. 
Table 7. List of down-regulated genes involved in ion metabolism and up-regulated genes that could be involved in drug resistance of $C$. gattii R265 10p cells.

\begin{tabular}{|c|c|c|c|}
\hline ORF & Genes identification & Function & $\begin{array}{l}\text { 10p/NA } \\
\text { Fold } \\
\text { change }\end{array}$ \\
\hline CNBG_0560 & $\begin{array}{c}\text { Solute carrier family } 31 \text { (copper } \\
\text { transporter), member } 1 \text { (CTR4) }\end{array}$ & $\begin{array}{l}\text { Copper ion } \\
\text { transmembrane } \\
\text { transport }\end{array}$ & -2.45 \\
\hline CNBG_6082 & $\begin{array}{l}\text { Ferric-chelate reductase } 7 \\
\text { (FRE7) }\end{array}$ & $\begin{array}{l}\text { Oxidoreductase } \\
\text { activity }\end{array}$ & -1.92 \\
\hline CNBG_9038 & Ferric-chelate reductase & $\begin{array}{l}\text { Oxidoreductase } \\
\text { activity }\end{array}$ & -1.62 \\
\hline$C N B G \_2627$ & Ferric-chelate reductase 1 (FRE1) & $\begin{array}{l}\text { Oxidoreductase } \\
\text { activity }\end{array}$ & -1.62 \\
\hline$C N B G_{-} 4400$ & $\begin{array}{l}\text { Cytochrome b2, mitochondrial } \\
(\text { cytb) }\end{array}$ & $\begin{array}{l}\text { Respiration } \\
\text { (target of } \\
\text { pyraclostrobin) }\end{array}$ & 2.058 \\
\hline$C N B G \_1200$ & $\begin{array}{l}\text { ATP-binding cassette transporter } \\
\qquad(A F R-1)\end{array}$ & Drug transport & 1.566 \\
\hline$C N B G \_1138$ & $\begin{array}{l}\text { Putative abc multidrug resistance } \\
\text { transporter with similarity to Ste6 } \\
\text { (MDR11) }\end{array}$ & Drug transport & 1.526 \\
\hline
\end{tabular}




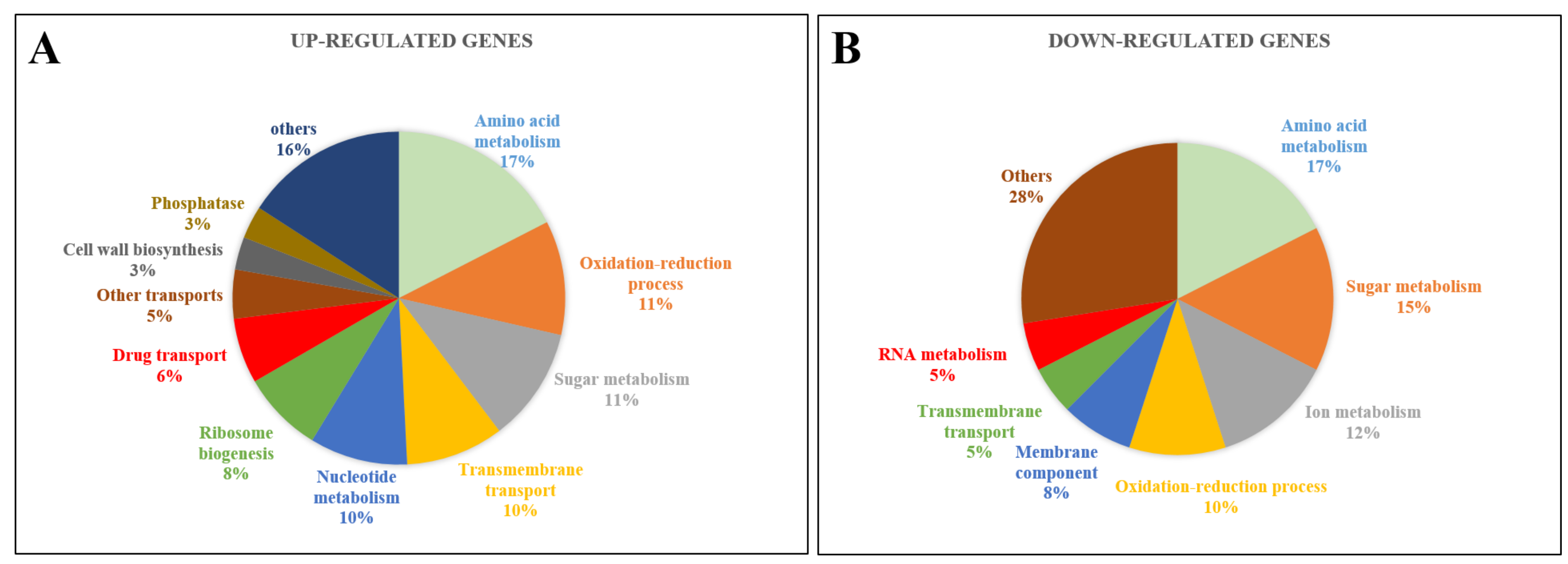

Figure 1: Transcriptomic profile of C. gattii R265 10p cells is different from that of NA cells.. Function of genes up- (A) and down-regulated

A

\section{in 10p cells compared to NA.}

\section{ed} (n)

$$
\text { of } C \text {. gattii R265 10p cells is different from that of NA cells.. Function of genes up- (A) and down-regulated }
$$

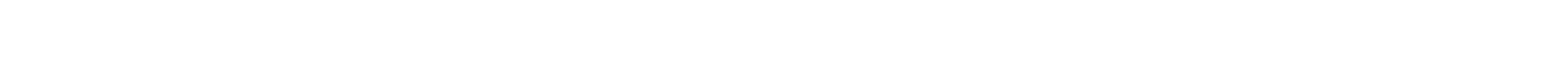

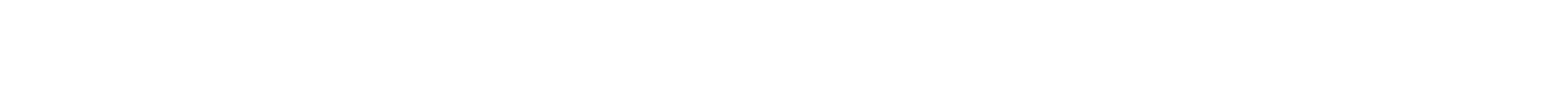


A

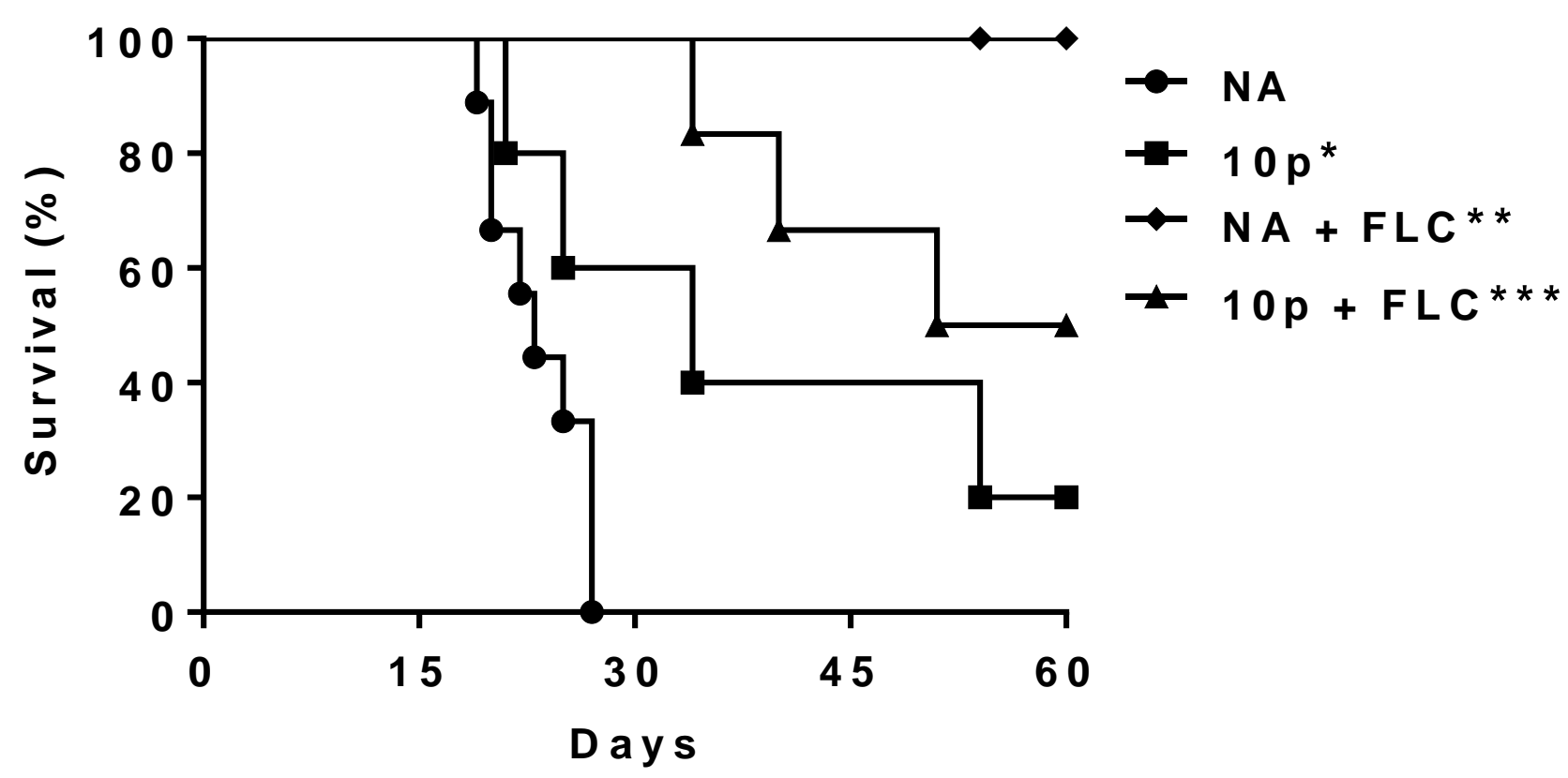

B

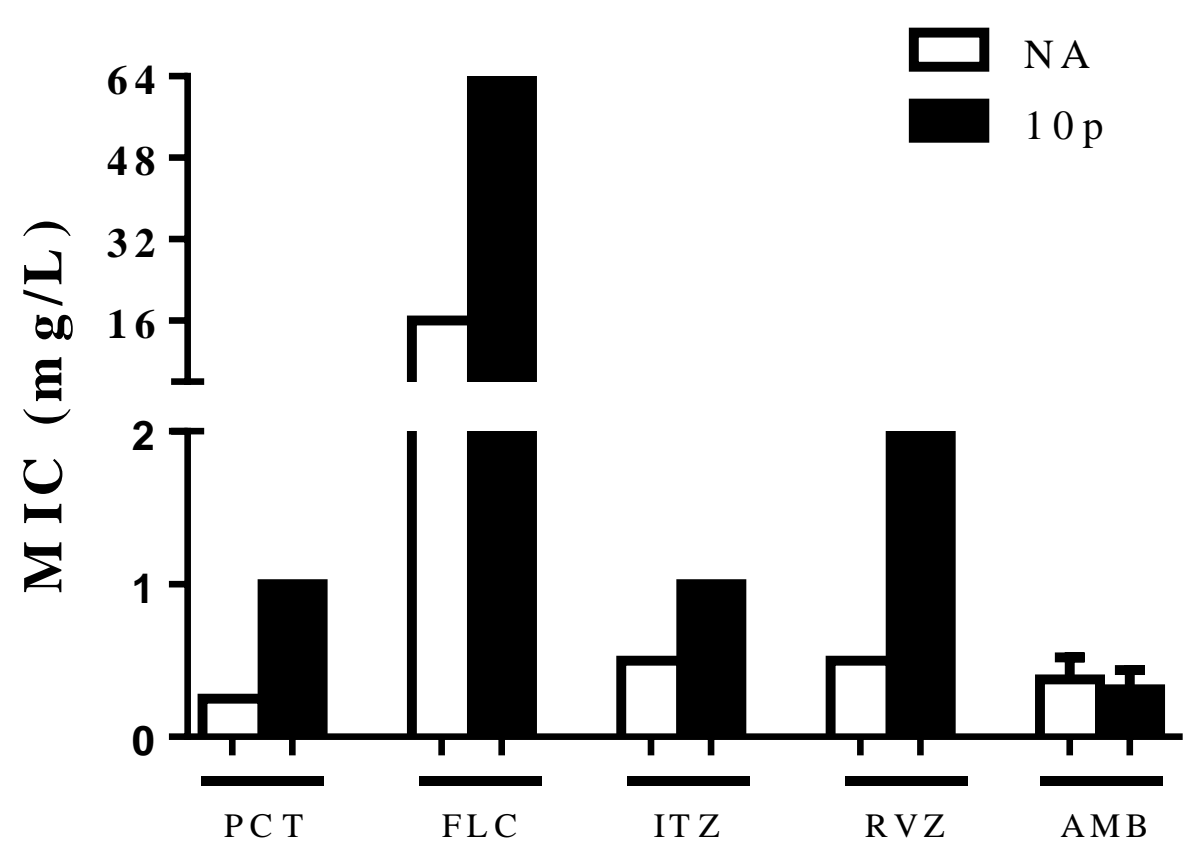

Figure 2: Virulence and in vivo Cross-resistance in non-adapted (NA) and adapted cells subcultivated in medium without agrochemical (10p). A) $10 \mathrm{p}$ cells are significatvely $(\mathrm{p}<0.05)$ less virulent than NA. The treatment with fluconazole $(\mathrm{FLC})$ significatvely $(\mathrm{p}<0.05)$ increased the survival of mice infected with NA, but not of those infected with 10p cells. B) Cells recovered from the lungs of animals infected with 10p colonies were more resistant to pyraclostrobin (PCT), fluconazole (FLC), itraconazole (ITZ) and ravuconazole (RVZ), but not to amphotericin B (AMB), than those recovered from NA-infected mice. ( $>0.05)$. ${ }^{*} p<0.05 ; * * p<0.01$ compared to NA group. 